\title{
What Makes Consumers Recall Banner Ads in Mobile Applications
}

\section{Mesut Çiçek}

Yalova University| mcicek@yalova.edu.tr

\section{İrem Eren-Erdoğmuş}

Marmara University|ireme@marmara.edu.tr

\section{İkram Daştan}

Yalova University|ikramdastan@gmail.com

Volume 7 No 1 (2017) ｜ＩSSN 2158-8708 (online) | DOI 10.5195/emaj.2017.122 | http://emaj.pitt.edu |

\begin{abstract}
The uses of mobile advertisements are increasing their popularity across the world. Companies can gather information about the mobile users based on their locations, lifestyle, and preferences via GPS, cookies and browsing history and embed highly personalized banner ads in mobile applications. However, in the literature there is hardly any work on the effectiveness of these highly personalized in-app banner ads. The aim of the study is to reveal which factors affect the effectiveness of in-app banner ads. An experimental study was designed and 209 subjects participated. The results of Ordinal Logistic Regression indicated that prior brand attitude and attitude towards application have a positive effect, while brand engagement with self-concept has a negative effect on the recall of in-app banner ads. Moreover, in-app banner ads are recalled more when they are located in landscape applications and positioned at the top part of the screen. This research provides some implications for future studies and practitioners.
\end{abstract}

Keywords: Mobile ads, Application, Banner advertising, In-App Banner Ads $(\mathrm{Cc}) \mathrm{EY}$

New articles in this journal are licensed under a Creative Commons Attribution 3.0 United States License.

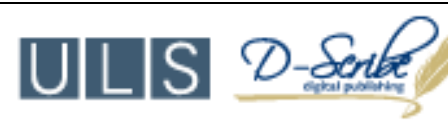

This journal is published by the University Library System of the University of Pittsburgh as part of its D-Scribe Digital Publishing Program, and is cosponsored by the University of Pittsburgh Press. 
What Makes Consumers Recall Banner Ads in Mobile Applications

\section{Mesut Çiçek \\ İrem Eren-Erdoğmuş \\ İkram Daştan}

\section{Introduction}

The uses of mobile advertisements are increasing their popularity across the world. This increase couples with the recent decline in traditional forms of communication in favor of a shift of attention to other media (e.g., Internet, mobile devices, social media) in the advertising industry (Siemens et al., 2015a). Mobile advertising provides several advantages to the companies such as high penetration rate, personal communication device, individual addressability, multimedia capability, and interactivity (Chang and Huo, 2011). Research also supports that mobile advertising outperforms non-mobile advertising (Rosenkrans and Myers, 2012; MediaMind, 2011). Mobile advertising providers monitor the online users' location, lifestyles, preferences and interests via GPS systems, emails, social media activities, cookies (Haddadi et al, 2010) and browsing history (Lambrecht and Tucker, 2013); then display the online ads of the products and services based on consumers' interests, locations, mobility patterns and daily habits (Haddadi et al, 2010). Despite this strong interest, most marketers still exert mixed if not negative view towards the effectiveness of mobile advertising (Bart et al., 2014), what makes one question whether marketers collect and use the right information in placing their in-app ads. Hence, more research is needed to explore how to enhance its effectiveness (Vatanparast and Butt, 2010; Nittala, 2011; Xie et al., 2013). The current research aims to contribute to the nascent mobile advertising literature by trying to understand which factors impact mobile advertising effectiveness (recall) by conducting an experimental research on in-app advertising. In-app advertising includes campaigns that are portrayed through mobile applications (Xie et al., 2013). The previously studied factors of advertising such as contextual factors (application orientation), advertisement factors (banner location), personal factors (brand engagement with self concept, product involvement, attitude towards application), and brand related factors (attitude) are adapted and examined this time for inapp mobile advertising effectiveness (recall) to provide a holistic view on this current and under investigated topic.

The sample of the research compromises of Generation Y consumers in Turkey. The statistics support that worldwide smartphone penetration is higher among these younger consumers (Bart, Stephen, and Sarvary, 2014), and it is acknowledged that they use multiple features of their smartphones consistently and continuously on social networking sites, and various applications (Jain and Pant, 2012; Bhave et. al., 2013). They are projected to enhance mobile commerce as they enter them prime income earning years and have more disposable income to spend (Emarketer, 2012). Therefore, this generation is suitable to study in-app mobile advertising.

\section{Conceptual Framework and Hypotheses Development}

Mobile advertising provides several advantages to the companies such as high penetration rate, personal communication device, individual addressability, multimedia capability, and interactivity (Chang and Huo, 2011). Mobile advertising providers monitor the online users' location, lifestyles, preferences and interests via GPS systems, emails, social media activities, cookies (Haddadi et al, 2010) and browsing history (Lambrecht and Tucker, 2013), then display the online ads of the products and services based on consumers' interests, locations, mobility patterns and daily habits (Haddadi et al, 2010). However, the effectiveness of these highly personalized ads has not been researched in the context of in app banner ads.

\subsection{BESC and Self-Brand Concept}

In order to understand in-app mobile banner ad recall, our research proposes that brand engagement with self concept (BESC) enhances the in-app mobile banner ad recall. BESC is defined as "an individual difference measure representing consumers' propensity to include important brands as a part of how they view themselves" (Sprott, Czellar \& Spangenberg, 2009, p. 92). It is a generalized conceptualization of the relationship of consumers with brands. Increased levels of BESC and brand-self connection create likelihood to include favorite brand/s with the self and increase strength of the brand/s in memory (Sprott, Czellar, and Spangenberg, 2009). Based on this discussion, our research proposes:

H1: Consumers' level of BESC positively increases recall of in-app mobile banner ads. 


\subsection{Product Involvement}

Product involvement refers to the personal relevance of the product, based on inherent needs, values, and interests of the consumer (Zaichkowsky, 1985). Level of involvement is determined with respect to how much active engagement is needed for productfocused judgment and decision-making (Petty, Cacioppo, and Schumann 1983; Zaichkowsky 1985). Consumers develop diversified involvement levels through product categories (Manzur et al., 2012). Low-involvement products are consumable items that require minimal effort and consideration before purchasing whereas high-involvement products entail more effort and consideration prior to their purchase. Recall, which requires sufficient attention, is more likely for high-involvement products. Consumers pay more attention to advertisements of products that they have high involvement with (Holbrook and Lehmann 1980) since they have more important personal consequences (Apsler and Sears 1968); therefore, are personally relevant and intrinsically important to consumers (Sherif and Hovland 1961). Thus:

H2: Consumers' level of involvement with a product category increases brand recall of inapp mobile banner ads.

\subsection{Brand Attitude}

It was Ehrenberg (1974), who first argued that consumers typically only pay attention to advertising of brands for which they have a pre-existing favorable attitude. As such, users of a brand have a higher recall in advertising of the brand and hold a favorable attitude towards its advertising (Rice and Bennett, 1998). Similarly, prior research in advertising recall suggests that well-known brands are better recalled than unfamiliar brands by consumers (Kent and Allen 2004; Nelson, Yaros, and Keum 2006; Schneider and Cornwell 2005). Nelson (2002), also showed in a series of experiments that a brand's market prominence in the consumer mind positively affected the recall of the brand in product placements. Similarly, in their study on product placement in computer games, Mackaya et. al (2009) also found out that pre-existing high positive attitudes resulted in higher levels of both spontaneous and prompted recall. In mobile advertising, Bhave, Jain and Roy (2013) found out that the recall was higher if the brand also used other media for advertisement as well and ensuring that consumers were already familiar with the brands. Similarly, the study by Siemens et al. (2015) located the positive impact of a well-known brand on brand recall within in-game advertising. Thus:

H3: Pre-existing positive brand attitude increases recall of in-app mobile banner ads.

\subsection{Attitude Towards Application}

According to the limited capacity model of mediated message processing (Lang, 2000), people have limited capacity information processing, and activate it automatically in response to motivationally relevant stimuli in the environment. Thus, whether a consumer has a positive or negative attitude towards mobile application may influence consumer motivation, their information processing, and their memory in return. Siemens et. al (2015b) concluded in their study that enjoyment and flow had a mediating positive influence on brand attitude in in- game advertising. Similarly, Yoo and Pena (2001) showed in their study that the negative associations of a violent video game elicited low brand recall in in-game advertising. Thus, it can be inferred from their results that consumer's attitude (liking) towards the mobile applications may divert or focus consumer attention on the ad, and hence have an impact on brand recall. Thus:

H4: Positive attitude towards the application increases recall of in-app mobile banner ads.

\subsection{Banner Location}

Since the screens of mobile phones are small, there are only limited places for banner ads within the applications. In-app mobile ads are mostly embedded at the top or bottom of the application (Woolridge and Schneider, 2011). Although there is hardly ever study about the effect of mobile banner location on the ad effectiveness, there are some studies about banner location's effectiveness in the context of computer web pages which come up with contradictory results. For example, Resnick and Albert (2014) revealed that top of the page is one of the most effective locations to get user's attention. On the other hand, Goodrich (2010) claimed that ads draw more attention when they are placed at the bottom of the page rather than at the top. Furthermore, Çalışır and Karaali (2008) indicated that there is no significant relationship between the banner location and advertising recognition. In the context of mobile applications, the thumbs of the users generally located around bottom of the screen. Therefore, the likelihood to miss the in-app banner ad is high when it is located at the bottom. Thus:

H5: Embedding banner ads at the top of applications increases recall of in-app mobile banner ads. 


\subsection{Application Orientation}

Mobile applications can be designed in two forms: landscape and portrait. The orientation of applications may affect the effectiveness of mobile banner ads since the holding position of the mobile phones and the dimensions of the banners are different for landscape and portrait orientations. In this context, it is hypothesized that;

H6: Application orientation affects recall of in-app mobile banner ads.

\section{Methodology}

In order to investigate the effects of application orientation (Landscape and Portrait) and banner location (Top and Bottom) on ad recall, an experimental study was designed. There were four experimental groups and subjects that were randomly assigned to each group and in each group there were at least 50 subjects. They were given a smart phone and requested to use a mobile application for 5 minutes. In order to prevent the possible effect of prior experiential effect, a professional mobile technology agency was hired to create two brand new applications (one is in portrait mode the other one is in landscape mode). The characteristics of experiment groups are shown in Table 1.

Table 1: The Characteristics of Experiment Groups

\begin{tabular}{|c|c|}
\hline $\begin{array}{c}\text { Subjects who used mobile } \\
\text { application in portrait mode } \\
\text { with the banner at the top } \\
\text { (N: 54) }\end{array}$ & $\begin{array}{c}\text { Subjects who used mobile } \\
\text { application in portrait mode } \\
\text { with the banner at the bottom } \\
\text { (N: 53) }\end{array}$ \\
\hline $\begin{array}{c}\text { Subjects who used mobile } \\
\text { application in landscape } \\
\text { mode with the banner at the } \\
\text { top } \\
\text { (N: } 51)\end{array}$ & $\begin{array}{c}\text { Subjects who used mobile } \\
\text { application in landscape } \\
\text { mode with the banner at the } \\
\text { bottom (N: 51) }\end{array}$ \\
\hline
\end{tabular}

Adidas was chosen as advertised brand, which is among the Lovemarks of Turkey. A dynamic mobile banner ad that consisted of three different screens was created. The ad included Adidas brand, background color, Adidas's slogan "Impossible is nothing", Messi's picture who is the brand ambassador of Adidas, and picture of Adidas shoes. Unaided advertising recall was used as the dependent variable of the study. The items used to measure advertising recall were adapted from $\mathrm{Li}$ and Bukovac's (1999) study. The subjects were first asked whether they noticed any banner ads while using the application. If the answer was a 'yes', then they were asked about the details of the advertisement to reveal their recall of the mobile banner ad. The subjects were not provided any cue about the banner advertising. The questions included "What was the brand in the banner?", "Who was the celebrity endorser in the banner?", "What is the brand slogan in the banner?", "Which product was endorsed in the banner?", "What color was used in the background of the banner?". Based on the answers, a recall score was calculated for each subject as an outcome variable which range between 0 and 5 . After the application of the experiment, the subjects were requested to fill a questionnaire which consisted of questions about their attitude towards the application (measure adopted from Muehling et al., 1991) that they used, attitude towards Adidas brand (Muehling et al., 1991), product category involvement (Seiders et al., 2007) towards sneakers, brand engagement with selfconcept (Sprott et al., 2009).

\section{Findings}

A total of 209 subjects (109 Male and 100 Female), who already owned a smart phone, participated in the study. Their ages ranged from 18 to 30 , with a mean of 23 and their education level varied from primary school graduation to $\mathrm{PhD}$ degree. Approximately $40 \%$ of the subjects have Undergraduate degree and $47 \%$ of them have high school degree. A Factor Analysis was conducted on the 14 items with Varimax rotation. The KMO measure verified the sampling adequacy, $\mathrm{KMO}=.77$. Bartlett's test of sphericity $\chi \mathrm{C} \quad(91)=2503, \mathrm{p}<.001$, indicated that correlations between items were sufficiently large for PCA. Four components had eigenvalues over Kaiser's criterion of 1 and in combination explained $75.51 \%$ of the variance. Table 2 shows the factor loadings after rotation.

Table 2: Factor Loadings of the Constructs

\begin{tabular}{|c|c|c|c|c|c|c|}
\hline & $\begin{array}{c}\text { Brand } \\
\text { Engagement }\end{array}$ & $\begin{array}{c}\text { Attitude } \\
\text { towards } \\
\text { Application }\end{array}$ & $\begin{array}{c}\text { Brand } \\
\text { Attitude }\end{array}$ & $\begin{array}{c}\text { Product } \\
\text { Category } \\
\text { Involvement }\end{array}$ & $\begin{array}{l}\text { Variance } \\
\text { Explained }\end{array}$ & $\begin{array}{c}\text { Cronbach's } \\
\text { a }\end{array}$ \\
\hline BE1 & 847 & & & 100 & \multirow{5}{*}{22.9} & \multirow{5}{*}{0.858} \\
\hline BE2 & 833 & & & & & \\
\hline BE4 & .784 & & & & & \\
\hline BE3 & .782 & & & & & \\
\hline BE5 & 699 & & & & & \\
\hline ATA1 & & 922 & & & \multirow{3}{*}{17.7} & \multirow{3}{*}{0.890} \\
\hline ATA3 & & .882 & & & & \\
\hline ATA2 & & 875 & & & & \\
\hline ATB1 & & & 903 & & \multirow{3}{*}{17.7} & \multirow{3}{*}{0.893} \\
\hline ATB3 & & & .889 & & & \\
\hline ATB2 & & & .882 & & & \\
\hline PCI1 & & & & 894 & \multirow{3}{*}{16.9} & \multirow{3}{*}{0.861} \\
\hline PCI2 & & & & .889 & & \\
\hline PCI3 & & & & .836 & & \\
\hline
\end{tabular}

Shapiro-Wilks statistics (.584, $\mathrm{p}<0.001)$ test indicated that recall score is not normally distributed. Therefore, to test the model Ordinal Logistic Regression was preferred. Insignificance of Test of Parallel Lines, which tests the proportional odds assumption, indicated that $(\chi 2(18)=27.31, \mathrm{p}>.05)$ the model is suitable for the OLP analysis. 
Table 3: Results of Ordinal Logistic Regression

\begin{tabular}{|c|c|c|c|c|c|c|c|}
\hline Parameter Estimates & \multirow[t]{2}{*}{ Estimate } & \multirow[t]{2}{*}{$\begin{array}{l}\text { Std. } \\
\text { Error }\end{array}$} & \multirow[t]{2}{*}{ Wald } & \multirow[t]{2}{*}{$\begin{array}{l}d \\
f\end{array}$} & \multirow[t]{2}{*}{$\begin{array}{l}\text { Odds } \\
\text { Ratio }\end{array}$} & \multicolumn{2}{|c|}{$\begin{array}{l}95 \% \text { Confidenc } \\
\text { Interval }\end{array}$} \\
\hline & & & & & & \begin{tabular}{c|} 
L. \\
Bound
\end{tabular} & $\begin{array}{c}\text { U. } \\
\text { Bound }\end{array}$ \\
\hline$[$ recall $=.00]$ & 2,63 & 1,64 & 2,57 & 1 & - & $-0,59$ & 5,85 \\
\hline$[$ recall $=1.00]$ & 2,76 & 1,64 & 2,82 & 1 & - & $-0,46$ & 5,98 \\
\hline$[$ recall $=2.00]$ & 3,76 & 1,66 & 5,15 & 1 & - & 0,51 & 7,00 \\
\hline$[$ recall $=3.00]$ & 4,20 & 1,66 & 6,39 & 1 & - & 0,95 & 7,46 \\
\hline Brand Attitude & $0,30 *$ & 0,17 & 3,33 & 1 & 1,355 & $-0,02$ & 0,63 \\
\hline \begin{tabular}{l|} 
Product Category \\
Involvement
\end{tabular} & 0,20 & 0,22 & 0,83 & 1 & 1,223 & $-0,23$ & 0,63 \\
\hline $\begin{array}{l}\text { Attitude Towards } \\
\text { Application }\end{array}$ & $0,49 * * *$ & 0,16 & 9,64 & 1 & 1,632 & 0,18 & 0,80 \\
\hline BESC & $-1,16^{* * *}$ & 0,25 & 2,20 & 1 & 0,314 & $-1,64$ & $-0,68$ \\
\hline [Portrait $=1.00]$ & $-0,65^{*}$ & 0,36 & 3,16 & 1 & 0,523 & $-1,36$ & 0,07 \\
\hline [Landscape $=2.00]$ & $0 \mathrm{a}$ & - & - & 0 & - & - & - \\
\hline$[\mathrm{Top}=1.00]$ & $1,57^{* * *}$ & 0,33 & 22,28 & 1 & 4,821 & 0,92 & 2,23 \\
\hline 要 $[$ Bottom $=2.00]$ & $0 \mathrm{a}$ & - & - & 0 & - & - & - \\
\hline \multicolumn{8}{|c|}{ Note: ${ }^{* * *} \mathrm{p}<0.001,{ }^{* *} \mathrm{p}<0.05,{ }^{*} \mathrm{p}<0.1$} \\
\hline \multicolumn{8}{|c|}{$\begin{array}{l}\text { Model Fit: } \gamma 2(6)=49.81, p<.001 \\
\text { Psedu } R^{2}=0.212 \text { (Cox \& Snell), } 0.243 \text { (Nagelkerke). }\end{array}$} \\
\hline \multicolumn{8}{|c|}{$\begin{array}{l}\text { Goodness of Fit: Pearson }=\chi^{2}(786)=781, p=0.541 \text {., Deivance }=\chi 2(786)=379 \\
p=1.000\end{array}$} \\
\hline
\end{tabular}

The results of Ordinal Logistic Regression analysis are shown in Table 3 . The significant chisquare statistic $(\mathrm{p}<.0001)$ indicates that the final model gives a significant R2 value (Nagelkerke $=.243$ ) indicates that independent variables explain approximately $25 \%$ of the ad recall. Parameter Estimates indicated that pre-existing brand attitude (H3: Supported) and attitude towards mobile application (H4: Supported) have positive effect on ad recall, while BESC (H1: Rejected) has negative effect. In addition, mobile banner ads are recalled more when the ads are located at the top (H5: Supported) of the screen and in landscape applications (H6: Supported). On the other hand, product involvement (H2: Rejected) has no significant effect on advertising effectiveness.

\section{Discussion and Conclusion}

This study was one of the preliminary studies in in-app mobile advertising research that tried to incorporate different factors of advertising effectiveness and test them together to foster knowledge in the field. Mobile advertising is a useful, novel method that have already bypassed traditional forms of advertising in terms of effectiveness and usage, given the increasing number of smartphone and application users. One of the key characteristics of mobile advertising is that it enables the advertiser to customize the advertising process according to individual likes, behavior, and preferences. Thus, it is important to understand which factors have an effect on advertising recall in in-app mobile advertising so that a direction could be provided to the practitioners on which dimensions to individualize their ads. The findings of this research are believed to help with this process.
The research puts forward a seemly positive effect of brand attitude and attitude towards the application on brand recall, highlighting the importance of attitudes on brand recall. Even though, attitude is treated as an outcome variable in most advertising research, this research preferred to treat it as an antecedent of brand recall and proved its effect on recall in in-app banner ads. This is one of the contributions of this research to existing literature. The implications of this result underline the importance of personalization in in-app ads for practitioners and offer perspective. Accordingly, mobile advertisers should track and identify individual consumer brand preferences through social media follows and likes; and place the ads of each consumer's most liked brands to applications that they use frequently. In other words, they should pay attention to both individual brand attitude/usage/purchase, and also application choice/usage/liking when deciding on in-app mobile banner ad strategy in order to increase ad effectiveness. As to the type of application and location of the banner, it is advisable for advertisers to choose landscape applications and locate the banner at the top of the screen.

An interesting finding of this research was that BESC has a negative impact on brand recall of in-app mobile banner ads. This was an unexpected result since it was thought that as people are more involved with brands and use them to define themselves, their likelihood of recall would be higher. One plausible explanation for this negative effect might be that the brand under question in this research (Adidas) may not be in the set that consumer engage with and use to define themselves. Given that brand attitude has a positive impact on brand recall contrary to BESC, it is possible that if the brand is among the prominent brands that consumers identify with, the recall will be higher. Thus, this finding needs further exploration. Additional factors such as brand self-connection might be added to the model to develop the research.

\section{REFERENCES}

Apsler, R., \& Sears, D. O. (1968). Warning, personal involvement, and attitude change. Journal of Personality and Social Psychology, 9(2p1), 162.

Bart, Y., Stephen, A. T., \& Sarvary, M. (2014). Which products are best suited to mobile advertising? A field study of mobile display advertising effects on consumer attitudes and intentions. Journal of Marketing Research, 51(3), 270-285. 
Bhave, K., Jain, V., Roy, S. (2013), 'Understanding the Orientation of Gen Y Toward Mobile Applications and In-App Advertising in India,' International Journal of Mobile Marketing, 8 (1), 62-74.

Chang, C. H., \& Huo, K. H. (2011). Mobile advertising: triple-win for consumers, advertisers and telecom carriers. In SIGIR Workshop on Internet Advertising, Beijing, China.

CMO Council (2012), Engage at Every Stage: The New Mobile Marketing Mandate. Palo Alto, CA: Chief Marketing Officer Council World Wide.

Ehrenberg, A. (1974) Repetitive advertising and the consumer. Journal of Advertising Research,14(2), 25-35.

Emarketer (2011), U.S. Digital Media Usage, retrieved from: http:/www.emarketer.com

Emarketer. (2012). U.S. mobile commerce forecast Retrieved from http://www.emarketer.com (accessed 30 January 2012).

Escalas, J. E. (2004), 'Narrative Processing: Building Consumer Connections to Brands,' Journal of Consumer Psychology, 14 (1-2), 168-180.

Haddadi, H., Hui, P., \& Brown, I. (2010, September). MobiAd: private and scalable mobile advertising. In Proceedings of the fifth ACM international workshop on Mobility in the evolving internet architecture (pp. 33-38). ACM.

Holbrook, M. B., \& Lehmann, D. R. (1980). The role of message content versus mechanical features in predicting recognition of print advertisements. Journal of Advertising Research, 20(1), 53-62.

Jain, V. and Pant, S. (2012), 'Navigating Generation Y Effective Mobile Marketing in India: A Conceptual Framework, International Journal of Mobile Marketing, 7 (3), 56-65.

Kent, R. J., \& Allen, C. T. (1994). Competitive interference effects in consumer memory for advertising: the role of brand familiarity. The Journal of Marketing, 97-105.
Lambrecht, A., \& Tucker, C. (2013). When does retargeting work? Information specificity in online advertising. Journal of Marketing Research, 50(5), 561-576.

Lang A. (2000). The limited capacity model of mediated message processing. Journal of Communication; 50:46-70.

Mackay, T., Ewing, M., Newton, F., \& Windisch, L. (2009). The effect of product placement in computer games on brand attitude and recall. International Journal of Advertising, 28(3), 423-438.

MediaMind (2011), iPhone, iPad yield double click rate to Android devices, retrieved from: http:/mediamind.com

Muehling, D. D., Laczniak, R. N., \& Stoltman, J. J. (1991). The moderating effects of ad message involvement: A reassessment. Journal of Advertising,20(2), 29-38.

Nelson, M. R. (2002). Recall of brand placements in computer/video games.Journal of advertising research, 42(2), 80-92.

Nelson, Michelle, Ronald A. Yaros, and Heejo Keum (2006), "Examining the Influence of Telepresence on Spectator and Player Processing of Real and Fictitious Brands in a Computer Game," Journal of Advertising, 35 (4), 87-99.

Nittala, R. (2011). Registering for incentivized mobile advertising: Discriminant analysis of mobile users. International Journal of Mobile Marketing, 6(1), 42-53.

Patel, Dev, Jeremy Schneider, and Kushan Surana (2013), "Cracking the Mobile Advertising Code," Harvard Business Review Blog Network, (September 11), (accessed February 27, 2014), [available at http://blogs.hbr.org/2013/09/cracking-themobileadvertisin/].

Petty, R. E., Cacioppo, J. T., \& Schumann, D. (1983). Central and peripheral routes to advertising effectiveness: The moderating role of involvement. Journal of consumer research, 135-146. 
Rice, B. \& Bennett, R. (1998) The relationship between brand usage and advertising tracking measurements: international findings. Journal of Advertising Research,38(3), pp. 5866 .

Rosenkrans, G. and Myers, K. (2012), 'Mobile Advertising Effectiveness,' International Journal of Mobile Marketing. Winter2012, 7 (3), 5-24.

Schneider, L. P., Systems, B., \& Cornwell, T. B. (2005). Cashing in on crashes via brand placement in computer games: The effects of experience and flow on memory. International Journal of Advertising, 24(3), 321-343.

Seiders, K., Voss, G. B., Godfrey, A. L., \& Grewal, D. (2007). SERVCON: development and validation of a multidimensional service convenience scale. Journal of the Academy of Marketing Science, 35(1), 144-156.

Seung-Chul Yoo, M.A., and Pena, J. (2011), Do Violent Video Games Impair The Effectiveness of In-Game Advertisements? The Impact of Gaming Environment on Brand Recall, Brand Attitude, and Purchase Intention, Cyberpsychology, Behavior, and Social Networking, 14 (7-8), 439-446.

Sherif, M., \& Hovland, C. I. (1961). Social judgment: Assimilation and contrast effects in communication and attitude change.Oxford, UK: Praeger Sie Siemens, J. C., Smith, S., Fisher, D., Thyroff, A., \& Killian, G. (2015). Level Up! The Role of Progress Feedback Type for Encouraging Intrinsic Motivation and Positive Brand Attitudes in Public Versus Private Gaming Contexts. Journal of Interactive Marketing, 32, 1-12.

Siemens, J. C., Smith, S., \& Fisher, D. (2015). Investigating the Effects of Active Control on Brand Recall Within In-Game Advertising. Journal of Interactive Advertising, 15(1), 43-53.

Sprott, D., Czellar, S., \& Spangenberg, E. (2009). The importance of a general measure of brand engagement on market behavior: Development and validation of a scale. Journal of Marketing Research, 46(1), 92104.
Vatanparast, R. and Butt, A.H. (2010), “An empirical study on study of factors affecting use of mobile advertising," International Journal of Mobile Marketing, 5 (1), 28-40.

Walsh, P., Kim, Y., \& Ross, S. D. (2008). Brand recall and recognition: A comparison of television and sport video games as presentation modes. Sport Marketing Quarterly, 17(4), 201-208.

Wooldridge, D., \& Schneider, M. (2011). Monetizing Free Apps with iAd and Other In-App Advertising Opportunities. In The Business of iPhone and iPad App Development (pp. 159-205). Apress.

Xie, W., Zhao, Y., and Xie, W. (2013), “The effects of interface design of hand-held devices on mobile advertising effectiveness among college students in China," International Journal of Mobile Marketing, 8 (1), 46-61.

Yoo, S. C., \& Peña, J. (2011). Do violent video games impair the effectiveness of in-game advertisements? The impact of gaming environment on brand recall, brand attitude, and purchase intention. Cyberpsychology, Behavior, and Social Networking, 14(7-8), 439-446.

Zaichkowsky, J. L. (1985). Measuring the involvement construct. Journal of consumer research, 341-352. 